\title{
An Anthropometric Study of Stature Estimation from Foot Morphometry in North Indian Population
}

\author{
Bhamini Sharma $^{1}$, Reena Singla ${ }^{2}$, Vishal Verma ${ }^{3}$ \\ ${ }^{1}$ M.Sc. Student, Department of Anatomy, ${ }^{2}$ Professor, Department of Anatomy, \\ ${ }^{3}$ Asstt. Prof. Department of Anatomy, MMIMSR, MMDU, Mullana-Ambala
}

\begin{abstract}
Background and Objectives: The aim of present study is to find the correlation of foot morphometry with stature and to derive the regression equation for stature estimation among two endogamous (baniya and jats) groups of North India.

Material and Method: The present study was carried out at Department of Anatomy, MMIMSR MullanaAmbala, on 400 subjects(100 males, 100 females of each group) belonging to known endogamous group (baniya and jats) of Haryana, age group ranged between 21-35 years. Height and foot length,foot breadth was measured. Foot index was calculated. Statistical analysis including mean, standard deviation for stature and foot morphometry of both sides were calculated separately for both sexes. Pearson's correlation coefficient was calculated to find correlation between stature and different foot morphometry .To estimate stature from foot morphometry linear regression analysis was done.

Results: The mean and standard deviation for height in males was $173.68 \pm 7.336$ and in females was $160.73 \pm 10.049$ with highly significant $p$ value. The mean foot length,foot breadth of males was higher than females with statistically significant $p$ value. In males, the foot length and foot breadth of both sides have a highly significant correlation with height. In females the correlation of height was highly significant with foot length, foot breadth and foot index among both the groups.

Conclusion: A significant correlation coefficient was observed between height and foot length in males. In females, a significant correlation was observed between height and foot length and foot breadth. If either of the measurement is known(height or foot length/foot breadth), the other can be calculated. This would be useful for Anthropologists and Forensic medicine experts.
\end{abstract}

Keywords: Foot length, Foot breadth, Foot index, jats, baniya, correlation.

\section{Introduction}

Anthropometry is a series of systematic measuring techniques that express quantitative dimensions of human body and skeleton. ${ }^{1}$ Forensic investigations

\footnotetext{
Corresponding Author:

Dr. Reena Singla

Professor, Department of Anatomy, MMIMSR, MMDU, Mullana-Ambala

e-mail: singla.reena@ymail.com

Mobile No.: 9896212241
}

use an anthropometric approach in the identification of victims. $^{2}$ Over the years, the anthropometric measurements of various anatomical structure for prediction and estimation of stature has become very useful,especially when the skeletal remains are often observed to be incomplete or extensively dismembered. ${ }^{3}$ Stature estimation has a very important role to play in forensic anthropometry for personal identification. Specifically, since each individual has different variations of body profile, estimating someones height can have an important role in an investigation. ${ }^{4}$ The stature of an individual is an inherent characteristic which varies with race and it is determined by genetic constitution 
of a person, geographical location, environment and the climatic conditions. With increasing frequency of mass disasters, it is essential to find out correlations between stature, age, and sex of an individual with variable information collected from different systems, organs or its parts which is of immense importance. ${ }^{5}$ Stature plays a key role in establishing the identity from unknown, decomposed and fragmented remains in medico legal cases. ${ }^{6}$ Human stature is an anatomical complex of linear dimensions,including skull,vertebral column,pelvis and lower extremities,so that it is assumed that significant association exist between the total stature and these individual body parts. ${ }^{7,8,9}$. Stature of a person is proportional to dimensions of various body parts. It is established that dimensions of lower extremity show higher association with stature than upper extremity. ${ }^{6}$

Height estimation by measurement of various long bones has been attempted by several workers. Each worker has derived own formula to estimate height from long bones. In 1968, Rutishauser for the first time showed that the reliability of prediction of height from foot length was as high as that from long bones. Ossification and maturation in the foot occurs earlier than the long bones and therefore,during adolescence age,height could be more accurately predicted from foot measurement as compared to that of long bones. ${ }^{10}$

Like other parts of body such as head,trunk,lengths of upper and lower limbs, the foot size also displays a definite biological correlation with stature on the basis of this relationship it is possible to predict the stature from foot and its segments. ${ }^{11}$ Various studies have reported a statistically significant positive association of stature with foot measurements. ${ }^{7,12}$ Some studies suggest the use of stature -foot index, multiplication factor method ${ }^{13,14,15}$ and regression equation method ${ }^{11}$ to estimate stature from foot dimensions. The aim of present study is to find the correlation of foot morphometry with stature and to derive the regression equation for stature estimation among two endogamous (baniya and jat) groups.

\section{Material and Method}

The present study was carried out at Department of Anatomy, MMIMSR Mullana -Ambala, on 400 subjects(100 males,100 females of each group) belonging to known endogamous group (baniya and jaat) of Haryana, age group ranged between 21-35 years .Prior written consent for the study was taken from all the subjects both in English and in vernacular. Cases with foot anomalies, trauma, inflammations and surgery was excluded for the investigation.

Equipments used: Osteometric board, Flexible metallic measuring tape.

Height was measured by making the subject stand erect and barefooted on a flat floor and the vertical distance between the point vertex, (highest point on the head), when the head is held in the Frankfurt's horizontal plane (which is obtained by joining the infra orbital margin to the upper margin of external acoustic meatus) and the heel touching the floor was measured in cms.

Foot measurements were taken with the help of osteometric board:

- Osteometric board: Osteometric board is an anthropometric instrument that consists of a flat board with two ends, one of which is movable and travels along a routed track. This is a preferred instrument for measuring long bones. The object to be measured is placed between the two end pieces and the movable end brought up to the object, where the measurement scale can be read.

- Foot length: Foot length was taken as a straight distance between the most posteriorly projecting points of heel (pternion) to the most anterior projecting point (Acropodion) of the first or the second toe whichever will be bigger when the foot is fully stretched.

- Foot breadth: Foot breadth was measured as a straight distance from metatarsaletibiale (the most medially placed point on the head of first metatarsal) and metatarsalefibulare (the most laterally placed point on the head of the fifth metatarsal) when the foot will be fully stretched.

- $\quad$ Foot index $=$ foot breadth/foot length $\times 100$

Statistical analysis: Data was analyzed using Statistical Package for Social Sciences (SPSS, version 20).Descriptive statistics including mean, standard deviation, minimum and maximum value for stature and foot morphometry of both sides were calculated separately for both sexes. Pearson's correlation coefficient was calculated to find correlation between stature and different foot morphometry. To estimate stature linear regression analysis was applied. 


\section{Results}

The mean and standard deviation for height in males was $173.68 \pm 7.336$ and in females was 160.73 \pm 10.049 with highly significant $p$ value. The mean foot length, foot breadth of males was higher than females with statistically significant $p$ value.(Table 1 ). In Baniya males, the foot length of both sides have a highly significant correlation with height at 0.01 level( 2 tailed) and foot breadth of both sides is significantly correlated with height at 0.05 level( 2 tailed). In Jat males, Right foot length and right foot breadth shows a correlation which is significant at 0.05 level ( 2 tailed) and left foot length and height are correlated and this correlation is highly significant at 0.01 level ( 2 tailed). The correlation of foot length, foot breadth and foot index in females of both the groups was highly significant at 0.01 level ( 2 tailed) as compared to the male group.(Table 2) The linear regression equations were applied on the parameters, which were highly correlated with height. In males, foot length (right and left) and in females, foot length(right) and foot breadth(left side). From these parameters, certain equations to estimate stature (dependent variable) from foot morphometry (Independent variable) are derived as follows: Linear regression equation to estimate height for various parameters studied in male and female group:

In Jats:

Height $=126.597+1.979($ Left foot length $)$

In baniya :

Height $=109.262+2.457$ (Right foot length)

Linear regression equation to estimate height for various parameters studied in females:

In Jats:

Height $=90.831+2.920($ Right Foot Length $)$

Height $=88.309+1.744$ (Right Foot Length $)+$ 3.318(Left Foot Breadth)

In baniya :

Height $=189.636-3.616($ Left Foot Breadth $)$

Height $=133.758+2.453($ Right Foot Length $)-$ 3.520 (Left Foot Breadth)

Table 1: Descriptive statistics of Age, Height and Foot morphometry among study population

\begin{tabular}{|l|l|c|c|c|}
\hline \multicolumn{2}{|l|}{ Parameters } & $\begin{array}{c}\text { Males (Mean } \pm \text { SD) } \\
\mathbf{N = 2 0 0}\end{array}$ & $\begin{array}{c}\text { Females (Mean } \pm \text { SD) } \\
\text { N=200 }\end{array}$ & p value \\
\hline Age & $24.80 \pm 3.759$ & $24.91 \pm 3.307$ & 0.7562 \\
\hline \multirow{2}{*}{ Height } & Right & $173.68 \pm 7.336$ & $160.73 \pm 10.049$ & $<0.001$ \\
\hline \multirow{2}{*}{ Foot Breadth } & Left & $9.59 \pm 1.136$ & $8.60 \pm 0.913$ & $<0.001$ \\
\hline \multirow{2}{*}{ Foot Length } & Right & $9.96 \pm 1.251$ & $8.86 \pm 0.986$ & $<0.001$ \\
\cline { 2 - 6 } & Left & $26.26 \pm 1.600$ & $23.48 \pm 1.846$ & $<0.001$ \\
\hline
\end{tabular}

Table 2: Correlation between stature and foot morphometry among study groups

\begin{tabular}{|c|c|c|c|c|c|c|c|c|}
\hline \multirow{2}{*}{$\begin{array}{l}\text { Study } \\
\text { Groups }\end{array}$} & \multirow[b]{2}{*}{ Sex } & \multirow{2}{*}{$\begin{array}{l}\text { Height } \\
\text { (Mean) }\end{array}$} & \multicolumn{4}{|c|}{ Correlation } & \multicolumn{2}{|c|}{ Foot Index } \\
\hline & & & $\begin{array}{l}\text { Right Foot } \\
\text { Length }\end{array}$ & $\begin{array}{l}\text { Right Foot } \\
\text { Breadth }\end{array}$ & $\begin{array}{l}\text { Left Foot } \\
\text { Length }\end{array}$ & $\begin{array}{c}\text { Left Foot } \\
\text { Breadth }\end{array}$ & Right Foot & Left Foot \\
\hline \multirow[t]{2}{*}{ Baniya } & Male & 170.626 & $0.000 * *$ & $\begin{array}{c}0.02 \\
7 *\end{array}$ & $\begin{array}{c}0.000 \\
* *\end{array}$ & $0.05^{*}$ & 0.337 & 0.49 \\
\hline & Female & 158.196 & $0.008 * *$ & $0.005 * *$ & $0.028^{*}$ & $0.001 * *$ & $0.000 * *$ & $0.000 * *$ \\
\hline \multirow{2}{*}{ Jat } & Male & 176.73 & $0.023^{*}$ & $0.035^{*}$ & $0.003 * *$ & 0.853 & 0.571 & 0.355 \\
\hline & Female & 162.791 & $0.000 * *$ & $0.000 * *$ & $0.000 * *$ & $0.000 * *$ & $0.044 *$ & $0.023 *$ \\
\hline
\end{tabular}

* Correlation is significant at the 0.05 level (2-tailed).

** Correlation is significant at the 0.01 level (2-tailed). 


\section{Discussion}

The present study focused on foot morphometry and its correlation with stature among two endogamous groups (Baniya, jats) of North India. It was seen that a significant correlation was seen between height and foot length in male study group. Among females, height is showing significant correlation with foot breadth, foot length and foot index (in jats and baniya females). (Table 2) Various previous studies conducted to find correlation between stature and foot morphometry agrees with our study. They concluded that there is significant correlation between height and various foot parameters as shown in Table 3.

Table 3: Comparison of correlation between stature and foot morphometry of present study with previous studies

\begin{tabular}{|l|c|c|c|l|}
\hline Study & Sample size & Males & Females & Parameters \\
\hline Present study & 400 & 200 & 200 & Height and foot length,foot breadth and foot index \\
\hline Patel SM et al ${ }^{16}(2007)$ & 502 & 278 & 224 & Height and foot length \\
\hline Mansur DI et al. ${ }^{17}(2012)$ & 440 & 258 & 182 & Height and foot length \\
\hline Shailesh M Patel et al ${ }^{18}(2011)$ & 285 & 149 & 136 & Height, foot length and foot breadth \\
\hline Mohantry BB et al $^{19}(2012)$ & 300 & 206 & 94 & Height and foot length \\
\hline Shankar GS et al ${ }^{20}(2018)$ & 234 & 98 & 136 & Height and foot length \\
\hline
\end{tabular}

Stature estimation is considered as one of the important parameters in identification of a person. various body parts shows biological correlation with stature. Therefore,many workers have utilized this fact to use body parts or skeletal remains to estimate stature. A study by Qamra et $\mathrm{al}^{21}$,measured height,foot length and foot breadth of 1015 adults (519 males and 496 females). They developed method for estimating height from foot morphometry. Sen et al ${ }^{22}$ studied the foot measurements and stature of Rajbanshis of West Bengal (150 males,150 females) and derive various formulas to evaluate height from foot morphometry. Kanchan et $\mathrm{al}^{23}$ studied the relationship between stature and foot dimensions among Gujjars, a north indian endogamous group . They measured height, foot length and foot breadth on 100 males and 100 females and derive multiplication factors and regression equations from foot dimensions to estimate stature. Dhaneria et $\mathrm{al},{ }^{24}$ concluded that foot length and foot breadth showed positive correlation with stature .out of both these parameters foot length is a better predictor of stature they also derive linear regression equation for estimation of stature from foot length and foot breadth.

\section{Conclusion}

The present study has established a strong correlation between height,foot length and foot breadth among study groups. Regression equation have also been established. In males, the correlation between height and foot length was more than foot breadth. In females, both foot breadth and foot length has significant correlation with height. In baniya females in addition to foot length and foot breadth,a significant correlation was seen between height and foot index. To conclude, foot length can be considered as a better predictor of stature in males than in females. Among comparison between endogamous groups in baniya females besides foot length and foot breadth, foot index is also a good predictor of stature. If either of the measurement (foot length,foot breadth,stature)is known the other can be calculated. However, these equations are population specific and cannot be applied to other population. Therefore,population specific studies are suggested that may be useful in examining dismembered human remains in medicolegal cases.

\section{Conflict of Interest: Nil}

\section{Source of Funding: Self}

Ethical Clearance: Ethical clearance and approval was obtained from the institutional Ethics Committee

\section{References}

1. Moitra S, Majumdar S, Lal N, Dey A. Estimation of height from foot length in Southern parts of 
West Bengal. Indian J of Med Res and Pharma Sci. 2017;4(6):31-36.

2. Jee S, Kwon S, Yun M H. Analysis of Stature prediction from foot anthropometry: A South Korean case study. Aus J of Forensic Sci.2017;49(1):9-21.

3. Paul C.W., Osuchukwu I.W, Aigbogun (Jr) E.O, Ekezie J. Stature estimation from foot dimensions of Igbo Indigenes of IMO State extraction in Nigeria. Int. J. of Recent Sci. Res. 2018;9(1): 23323-27.

4. Taneja C, Babel H, Jain LK. An anthropometric study of stature estimation among males from the measurements of feet in Udaipur District of Rajasthan. Int J Cur Res Rev. 2016;8(17):41.

5. Tandon R, Yunus S, Faruqui N, Asghar A. Measurements of hand and foot- A predictor of stature in adult human population of Uttar Pradesh Int J Anat Radio Sung. 2016;5(1):12-5.

6. Bumbrah GS. Prediction of stature from foot dimensions in a jat sikh population of North India. Malaysian Journal of Forensic Sciences, 2018,8(1):14-12.

7. Ozaslan A,Iscan MY,Ozaslan I, Tugcu H,Koc S. Estimation of stature from body parts. Forensic sci Int. 2003;132:40-5

8. Cordeiro C, Munoz - Barus JI, Wasterlain S, Cunha E, Viera DN. Predicting adult stature from metatarsal length in a Portuguese population. Forensic Sci Int 2009;193:131-134

9. Ahmed AA.Estimation of stature using lower limb measurements in Sudanese Arabs.J Forensic Leg Med. 2013;20:483-8

10. Rutishauser IHE. Prediction of height from foot length: use of measurement in field survey. Arch Dis Child 1968;43 : 310

11. Krishan K, Kanchan T, Passi N. Estimation of stature from foot and its segmentsin a sub-adult female population of North India. J Foot Ankle Res. 2011;Nov;4:24

12. Fessler DM, Haley KJ, Lal RD. Sexual dimorphism in foot length proportionate to stature. Ann Hum Biol. 2005;32:44-59

13. Sharma VK, Garg RK, Chattopadhyay PK. Calculation of stature from foot measurements: a study of Gaur Brahmins. Coll Anthropol. 1978;2:194-5
14. Jasuja OP, Singh J, Jain M. Estimation of stature from foot and shoe measurements by multiplication factors: a revised attempt. Forensic Sci Int. 1991;50:203-15

15. Charnalia VM. Anthropological study of the foot and its relationship to stature in different castes and tribes of Pondicherry state. J Anat Soc India. 1961;10:26-31

16. Patel SM, Shah GV, Patel SV. Estimation of height from measurement of foot length in Gujarat region. J. Anat. Soc. India. 2007;56(1):25-27.

17. Mansur DI, Haque MK, Sharma K, Karki RK, Khanal K, Karna R . Estimate of stature from foot length in adult Nepalese population and its clinical relevance. Kathmandu Univ Med J. 2012;37(1):169

18. Patel SM, Doshi V, Ruparelia S, Zalawadia A, Parekh D, Rathod SP, et al. Anthropological study of the Foot and it's relationship between different parameters and Stature in an Adult Population of Different areas of Gujarat. NJIRM. 2011;2(3):6770.

19. Mohanty BB, Agarwal D, Mishra K, Samantsinghar $\mathrm{P}$, Chinara PK. Estimation of height of an individual from foot length: A Study on the Population of Odisha. Int J Rev Life Sci. 2012;2(2):67-74.

20. Shankar GS, Shankar VV, Shetty S,KR . Correlation of human height with foot length in Indian Individuals . Int J Anat Res 2018, Vol 6 $(1,2): 4943-46$.

21. Qamra SR,Jit I,Deodhar SD. A model for reconstruction of height from foot measurements in adult population of North-West India.Indian J Med Res Jan 1980;71: 77-83

22. Sen J, Ghosh S. Estimation of stature from foot length and foot breadth among the Rajbhanshi: An Indigenous population of North Bengal. J Forensic Sci Int. 2008 Oct;181(1-3):55.el-55.e6

23. Kanchan $T$, Menezes RG, Moudgil R,Kaur R,Kotian MS,Garg KR. Stature estimation from foot dimensions. Forensic Sci Int. 2008;179(23):241.el-241e.5

24. Dhaneria V,Shrivastava M,Mathur RK,Goyal S. Estimation of height from measurement of foot breadth and foot length in adult population of Rajasthan. Indian J Clin Anat Physiol. 2016:3(1)7882. 